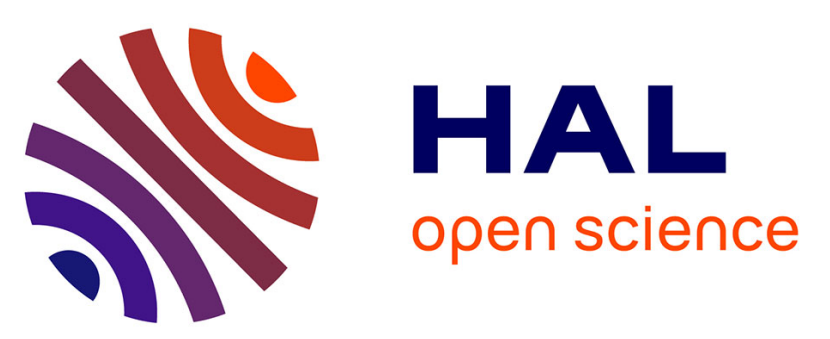

\title{
Assessment of VEGF-receptor system expression in the porcine endometrial stromal cells in response to insulin-like growth factor-I, relaxin, oxytocin and prostaglandin $\mathrm{E}$
}

\author{
Monika M. Kaczmarek, Agnieszka Blitek, Katarzyna Kaminska, Gabriel \\ Bodek, Marek Zygmunt, Dieter Schams, Adam J. Ziecik
}

\section{To cite this version:}

Monika M. Kaczmarek, Agnieszka Blitek, Katarzyna Kaminska, Gabriel Bodek, Marek Zygmunt, et al.. Assessment of VEGF-receptor system expression in the porcine endometrial stromal cells in response to insulin-like growth factor-I, relaxin, oxytocin and prostaglandin E. Molecular and Cellular Endocrinology, 2008, 291 (1-2), pp.33. 10.1016/j.mce.2008.04.020 . hal-00532024

\author{
HAL Id: hal-00532024 \\ https://hal.science/hal-00532024
}

Submitted on 4 Nov 2010

HAL is a multi-disciplinary open access archive for the deposit and dissemination of scientific research documents, whether they are published or not. The documents may come from teaching and research institutions in France or abroad, or from public or private research centers.
L'archive ouverte pluridisciplinaire HAL, est destinée au dépôt et à la diffusion de documents scientifiques de niveau recherche, publiés ou non, émanant des établissements d'enseignement et de recherche français ou étrangers, des laboratoires publics ou privés. 


\section{Accepted Manuscript}

Title: Assessment of VEGF-receptor system expression in the porcine endometrial stromal cells in response to insulin-like growth factor-I, relaxin, oxytocin and prostaglandin $\mathrm{E}_{2}$

Authors: Monika M. Kaczmarek, Agnieszka Blitek, Katarzyna Kaminska, Gabriel Bodek, Marek Zygmunt, Dieter Schams,

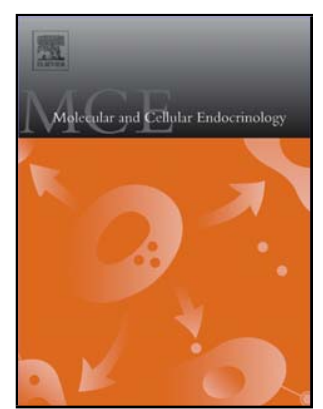
Adam J. Ziecik

PII:

S0303-7207(08)00157-3

DOI: doi:10.1016/j.mce.2008.04.020

Reference: MCE 6870

To appear in: $\quad$ Molecular and Cellular Endocrinology

Received date: 28-9-2007

Revised date: $\quad 20-4-2008$

Accepted date: $\quad$ 28-4-2008

Please cite this article as: Kaczmarek, M.M., Blitek, A., Kaminska, K., Bodek, G., Zygmunt, M., Schams, D., Ziecik, A.J., Assessment of VEGF-receptor system expression in the porcine endometrial stromal cells in response to insulin-like growth factor-I, relaxin, oxytocin and prostaglandin $\mathrm{E}_{2}$, Molecular and Cellular Endocrinology (2007), doi:10.1016/j.mce.2008.04.020

This is a PDF file of an unedited manuscript that has been accepted for publication. As a service to our customers we are providing this early version of the manuscript. The manuscript will undergo copyediting, typesetting, and review of the resulting proof before it is published in its final form. Please note that during the production process errors may be discovered which could affect the content, and all legal disclaimers that apply to the journal pertain. 
1 Assessment of VEGF-receptor system expression in the porcine endometrial stromal

2 cells in response to insulin-like growth factor-I, relaxin, oxytocin and prostaglandin $\mathbf{E}_{2}$

6 Monika M. Kaczmarek ${ }^{\mathrm{a}, *}$, Agnieszka Blitek ${ }^{\mathrm{a}}$, Katarzyna Kaminska ${ }^{\mathrm{a}}$, Gabriel Bodek ${ }^{\mathrm{a}}$, Marek 7 Zygmunt $^{\mathrm{b}}$, Dieter Schams ${ }^{\mathrm{c}}$, Adam J. Ziecik ${ }^{\mathrm{a}}$.

11 Division of Reproductive Endocrinology and Pathophysiology, Institute of Animal

12 Reproduction and Food Research, Polish Academy of Sciences, Olsztyn, Poland

$13{ }^{b}$ Department of Obstetrics and Gynecology, University of Greifswald, Greifswald, Germany

$14{ }^{c}$ Physiology Weihenstephan, Technical University Munich, Freising, Germany

*Corresponding author at: Institute of Animal Reproduction and Food Research Polish

23 Academy of Sciences (IARFR PAS), Tuwima 10, 10-747 Olsztyn, Poland. Tel.: +48 89

$24 \quad 5357422 ;$ fax: +48 895357421 .

25 E-mail: moka@pan.olsztyn.pl (M.M. Kaczmarek) 
1 Keywords: angiogenesis; VEGF-receptor system; endometrium; early pregnancy

2

3 Abstract

4 Several factors participate in regulation of growth and development as well as

5 angiogenesis of the uterus during pregnancy, and hence little is known about the role of

6 hormonal regulation of vascular endothelial growth factor (VEGF)-receptor system

7 expression. This study has examined the effect of insulin-like growth factor-I (IGF-I), relaxin

8 (RLX), oxytocin (OT) and prostaglandin (PG) $\mathrm{E}_{2}$, on VEGF secretion and VEGF-receptor

9 system mRNA expression in the porcine endometrial stromal cells. IGF-I and RLX were

10 identified as the most effective inducers of VEGF secretion and mRNA expression. Although

$11 \mathrm{PGE}_{2}$ stimulated VEGF secretion and VEGF164 mRNA expression, OT inhibited both

12 secretion and mRNA expression of VEGF. When tested for VEGF receptors (R), all factors

13 failed to affect their mRNA expression. Media conditioned by stromal cells collected after

14 IGF-I and RLX treatment significantly increased endothelial cell proliferation and this effect

15 was blocked by soluble VEGFR-1. These data suggest that during early pregnancy IGF-I,

16 RLX and $\mathrm{PGE}_{2}$ can affect VEGF expression in the endometrium and therefore may support

17 uterine and embryo development, implantation and pregnancy. 


\section{1. Introduction}

2 Periimplantation is a critical period during early pregnancy, when synchronization

3 between developing embryo and maternal uterus must occur to ensure proper initiation of

4 embryo attachment and implantation. More specifically, the embryo must reach the blastocyst

5 stage and gain 'implantation competence'; meanwhile, the uterus must reach the receptive

6 phase (Dey et al., 2004). In pigs, as in other species, the embryo-maternal crosstalk is

7 essential to gain such synchronization. This dialogue is regulated by several biological

8 molecules, including growth factors, cytokines, prostaglandins and hormones (for a review

9 see Ziecik et al., 2006).

10 Early pregnancy is associated with morphological and functional changes in the uterus,

11 accompanied by vascular remodeling. One of the first reactions on the embryo-derived

12 estrogenic signal is increased uterine blood supply. In pigs, increased uterine arterial blood

13 flow was observed on days 11-13 of pregnancy (Ford and Christenson, 1979; Ford et al.,

14 1982) and is thought to support prostaglandin production in the endometrium and corpus

15 luteum (CL) functions. Moreover, early stages of embryo implantation are characterized by

16 increased endometrial vascular permeability in many species, including primates (Enders et

17 al., 1983), rodents (Psychoyos, 1973), sheep (Boshier, 1970) and pigs (Keys et al., 1986; Keys

18 and King, 1988). In general, increased permeability is thought to play an essential role in the

19 induction and direction of tissue growth and remodeling wherever it occurs (Dvorak et al.,

20 1995). Thus it may be a basic requirement for the rapid growth and differentiation of

21 endometrium to reach the receptive phase. In addition, increased permeability facilitates the angiogenesis associated with the maternal component of placenta formation (Dvorak et al., 23 1995).

24 The most potent inducer of angiogenesis as well as microvascular permeability yet 25 identified is vascular endothelial growth factor (VEGF). The various forms of VEGF are 
1 generated by alternative splicing of single gene. Four different isoforms of VEGF were

2 initially reported in humans VEGF121, VEGF165, VEGF189, VEGF206 (Ferrara et al., 1991;

3 Tischer et al., 1991), however, to date several less frequent and tissue specific splice variants

4 have also been reported, for example VEGF145 and VEGF183 (Anthony et al., 1994; Lei et

5 al., 1998). VEGF activity is mainly mediated by two high affinity tyrosine kinase receptors

6 (R); VEGFR-1 (fms-like tyrosine kinase, Flt-1) and VEGFR-2 (fetal liver kinase-1/kinase

7 insert domain-containing receptor, Flk-1/KDR; Ferarra et al., 2003).

8 It is believed that VEGF play important roles during implantation. Experiments in 9 rodents have indicated that VEGF participates in vascular events before implantation, regulating periimplantation vascular permeability (Rabbani and Rogers, 2001). Rockwell et

11 al. (2002) showed that VEGF is the major mediator of estrogen-induced uterine microvascular

12 permeability and is absolutely essential for implantation in mice. In pigs, vessel permeability

13 appeared in conjunction with blastocyst elongation at day 12 (Keys et al., 1986). Recently,

14 increased VEGF164 protein expression was found in porcine endometrium on days 9-15 of

15 pregnancy (Kaczmarek et al., 2008), suggesting its possible participation in implantationassociated vascular events.

17 The endometrial growth and remodeling require the coordinated expression of many genes, and for many of these the estrogen receptor (ER) is an essential component of 19 transcriptional complex. In pigs, during maternal recognition of pregnancy estrogenic signal 20 of blastocyst occurs between days 10-12 of gestation (Geisert et al., 1982) and regulates 21 expression of numerous genes by binding to and activating ER. Among the genes identified as targets for regulation by the estradiol/ER complex in the uterus is that encoding $\underline{V E G F}$ (Hyder et al., 1997) and insulin-like growth factor-I (IGF-I; Klotz et al., 2002), both increased in the

24 uterus during early pregnancy in the pig (Letcher et al., 1989; Kaczmarek et al., 2008).

25 Furthermore, relaxin (RLX), like estrogens, promotes the growth of the uterus and other 
1 estrogen target tissues, since they share the ability to activate ER (Pillai et al., 1999).

2 Although, serum RLX levels during early pregnancy in pigs are maintained low (Anderson et 3 al., 1983), its mRNA and protein are present in the endometrium between days 10-20 of 4 gestation (Knox et al., 1994).

It has been suggested that, besides estrogens, uterine synthesis of prostaglandins (PG)

6 is a critical element of successful implantation in many domestic animals, including pigs (for

7 a review see Ziecik et al., 2006). A dramatic increase in the $\mathrm{PGE}_{2} / \mathrm{PGF}_{2 \alpha}$ ratio is observed in

8 the uterine lumen and utero-ovarian vein of pregnant animals on days 11-12 (Davis and Blair,

9 1993; Christenson et al., 1994), suggesting that $\mathrm{PGE}_{2}$ can overcome the luteolytic effect of

$10 \mathrm{PGF}_{2 \alpha}$ and maintain the function of CL. Furthermore, it was suggested that maintenance of

11 pregnancy in pigs is also mediated by oxytocin (OT), a potent inducer of uterine $\mathrm{PGF}_{2 \alpha}$

12 secretion (Carnahan et al., 1996; Edgerton et al., 1996), since a low concentration of OT

13 receptors (OTR) in the endometrium of early pregnant pigs was found (Okano et al., 1996).

14 However, several other results suggest that the OT-receptor system may not be mandatory in

15 the establishment of pregnancy in pigs (for a review see Ziecik et al., 2006).

16 Knowledge about the regulators of endometrial VEGF-receptor system expression is

17 rather limited. Therefore, to better identify the role of VEGF and its receptors in the 18 endometrium during the periimplanation period, we investigated whether VEGF-receptor 19 system expression in porcine endometrial stromal cells could be affected by IGF-I, RLX, OT 20 and $\mathrm{PGE}_{2}$.

\section{Materials and methods}

\subsection{Materials}

Chemicals were obtained from Sigma (St Louis, MO, USA), unless otherwise indicated. The recombinant bovine VEGF164 was a kind gift from Dr. D. Gospodarowicz 
1 (Chiron Corp., Barkeley, CA, USA). Purified porcine RLX was a generous gift from Dr. O.D.

2 Sherwood (University of Illinois at Urbana-Champaign, IL, USA).

3

\subsection{Primary cell culture and treatment}

The endometrial tissue was collected on days 10-12 of pregnancy from 17 crossbred

6 gilts of known breeding date. Pregnancy was confirmed by the presence of at least four

7 conceptuses in the uterine horns. The concepti were flushed from uterine horns with $20 \mathrm{ml}$ of

8 phosphate-buffered saline (PBS; $\mathrm{pH} 7.4)$ at $37^{\circ} \mathrm{C}$. Porcine endometrial stromal cells were

9 isolated from the middle portion of the uterine horn using a procedure described earlier

10 (Blitek and Ziecik, 2004). The cell viability was higher than $90 \%$ as assessed by $0.5 \%$ trypan

11 blue dye exclusion. Cells were cultured in Medium 199 containing 2\% BSA (ICN,

12 Biomedicals, Inc., Costa Mesa, CA, USA), $10 \%$ NCS and $20 \mu \mathrm{g} / \mathrm{ml}$ gentamycin at $37^{\circ} \mathrm{C}$ in a

13 humidified atmosphere of $95 \%$ air $/ 5 \% \mathrm{CO}_{2}$. After $24 \mathrm{~h}$ of seeding $\left(2.5 \times 10^{5}\right.$ for secretion

14 studies or $1.5 \times 10^{6}$ for gene expression studies) on culture plates (24- or 6-well plates), stromal

15 cells were washed gently with PBS to remove contaminating epithelial cells. Afterwards, cells

16 were additionally cultured for $24 \mathrm{~h}$ to allow complete cell adhesion before initiation of the

17 experiment, until approximately $80-90 \%$ confluency. The purity of stromal cell culture was

95-98\% as assessed by immunofluorescent staining for the presence or absence of vimentin and cytokeratin (Blitek and Ziecik, 2004).

Forty eight hours after plating, the medium was changed for fresh Medium 199 containing 0 (no treatment, control); 25-100 ng/ml RLX; 10-100 ng/ml IGF-I; 1-100 nM OT or 0.001-1 $\mu \mathrm{M} \mathrm{PGE}_{2}$ (Cayman Chemical, MI, USA). For dose and time-dependent studies,

23 liquid medium was collected after $6,12,24$ or $48 \mathrm{~h}$ of treatment and stored at $-40^{\circ} \mathrm{C}$. Cells

24 were then washed with PBS, lysed with $100 \mathrm{mmol} / \mathrm{l} \mathrm{NaOH}$ and total cellular protein content was measured (Bradford, 1976). For gene expression studies, treatments were performed for 
$124 \mathrm{~h}$, cells were washed with PBS and total RNA was extracted. All experiments were

2 performed in duplicates.

3

$4 \quad 2.3$ Immunofluorescence for VEGF

For immunofluorescent staining, isolated porcine endometrial stromal cells were grown on sterile plastic coverslips (Nunc, Rochester, NY, USA) inserted into 24-well plates. After $24 \mathrm{~h}$ of culture stromal cells were washed gently with PBS to remove contaminating cells and further cultured for $24 \mathrm{~h}$ to $90 \%$ confluency. Then, cells were washed gently with PBS, fixed in $4 \%$ paraformaldehyde in PBS for $10 \mathrm{~min}$ at room temperature and rinsed three times for 10 min with PBS. After $1.5 \mathrm{~h}$ at room temperature in blocking solution (1\% BSA, $10 \%$ NDS in PBS), cells were incubated overnight at $4^{\circ} \mathrm{C}$ with antiserum for VEGF (Santa Cruz Biotechnology, Inc., Santa Cruz, CA, USA) diluted 1:100. In control staining, primary antibodies were omitted. Next day, cells were washed three times for 10 min with PBS and secondary antibodies (CY3- anti-rabbit; Jackson ImmunoResearch, West Grove, PA, USA) at a dilution of 1:300 were added for $2 \mathrm{~h}$ at room temperature. At the end of incubation coverslips were rinsed with PBS, mounted on slides with a mixture of glycerol and PBS $(1: 1)$, viewed with Olympus microscope (Olympus BX 40; Olympus Optical Co Ltd, Tokyo, Japan) equipped with a filter set for CY3 and photographed with a Olympus Digital Camera.

\subsection{Radioimmunoassay (RIA) for VEGF}

Concentrations of VEGF in media were measured by RIA according to the method described earlier (Berisha et al., 2000). Briefly, the recombinant bovine VEGF164 was used for preparation of rabbit antiserum and iodination. The incubation buffer for RIA was $3 \mathrm{M}$ $\mathrm{NaCl}$ containing $1 \% \mathrm{BSA}, 0.1 \%$ Triton $\mathrm{X}-100(\mathrm{pH} 7.5)$. The antiserum was used at a final dilution of 1:400 000. Separation of bound and free VEGF was completed using the double 
1 antibody technique and 6\% polyethylene glycol (Serva, Heidelberg, Germany). The intra-

2 assay variations were below $6 \%$ and the inter-assay variations below $14 \%$. The ED 50 of the 3 assay was $0.6 \mathrm{ng} / \mathrm{ml}$. Dilution of samples containing VEGF from blood plasma, follicular

4 fluid and tissue extracts ran parallel to the standard curve. The average recovery of exogenous 5 VEGF was 93-95\%.

6

$7 \quad 2.5$ Reverse transcription and Real-Time PCR

8 Total RNA was prepared using Total RNA Prep Plus kit (A\&A Biotechnology,

9 Gdansk, Poland) according to the manufacturer's instructions. Constant amounts of $2 \mu \mathrm{g}$ of

10 total RNA were treated with DNase I (Invitrogen Life Technologies, Inc., Carlsbad, CA, 11 USA) as described in supplier's protocol. The RT reaction was carried out according to the 12 protocol detailed previously (Kaczmarek et al., 2007). RT products were diluted fourfold in 13 sterile water and stored at $-20^{\circ} \mathrm{C}$ until Real time PCR amplification.

14 Real time PCR was performed with an ABI Prism 7300 sequence detection system 15 using SYBR green PCR master mix (Applied Biosystems, Foster City, CA, USA) as 16 described elsewhere (Kaczmarek et al., 2007, Kowalczyk et al., 2008). Table 1 shows the 17 oligonucleotide primers used for PCR amplification of VEGF, VEGF164, VEGF120, VEGFR-

$18 \underline{1, V E G F R-2}$ and $\underline{\beta \text {-actin }}$ genes and expected product sizes. Serial dilutions of the appropriate 19 DNA were used as standard curves. The following general PCR conditions were used: 20 denaturation for $10 \mathrm{~min}$ at $95^{\circ} \mathrm{C}$, followed by 35 cycles of $15 \mathrm{sec}$ at $95^{\circ} \mathrm{C}$ and $1 \mathrm{~min}$ at $59^{\circ} \mathrm{C}$ 21 (for VEGFR-1) or $60^{\circ} \mathrm{C}$ (for VEGF, VEGF 164, VEGF 120, VEGFR-2, and $\beta$-actin). Melting 22 curves were obtained after each PCR reaction. The reactions were also run either on blankonly buffer samples or in absence of the reverse transcriptase. The specificity of RT/PCR

24 products was confirmed by gel electrophoresis and sequencing. Data obtained from the Real 
1 time PCR for VEGF, VEGF164, VEGF120, VEGFR-1 and VEGFR-2 were normalized on the

2 basis of $\beta$-actin mRNA content.

$4 \quad 2.6$ Endothelial cell proliferation assay

6 chemical reduction of growth indicator alamarBlue ${ }^{\mathrm{TM}}$ (Serotec Ltd., Oxford, UK). Human

7 umbilical vein endothelial cells (HUVEC) at passage one to four were allowed to adhere and

8 spread on 96-well dishes for $18 \mathrm{~h}\left(1 \times 10^{4}\right.$ cells/well) in 10\% NCS MCDB 131 supplemented

9 with antibiotics (100 IU/ml penicillin, $100 \mu \mathrm{g} / \mathrm{ml}$ streptomycin). Cells were first pretreated

10 with or without soluble VEGFR-1 or VEGFR-2 (100 ng/ml; sVEGFR-1, sVEGFR-2; Abcam,

11 Cambridge, UK) in MCDB 131 for $40 \mathrm{~min}$. Afterwards, 35\% of conditioned medium

12 collected during VEGF secretion studies (24 or $48 \mathrm{~h}$ treatment with IGF or RLX, selected in

13 preliminary experiments) in 2\% NCS MCDB 131, alone or in combination with $100 \mathrm{ng} / \mathrm{ml}$

14 sVEGFR-1 or sVEGFR-2 was added to each well in duplicates and incubated for 3 days.

15 VEGF (10 ng/ml; PeproTech EC Ltd., London, UK) was used as positive control.

16 Conditioned media were then replaced by fresh MCDB 131 containing $10 \%$ of alamarBlue ${ }^{\mathrm{TM}}$

17 reagent and incubated for $7 \mathrm{~h}$. Absorbance was measured at 570 and $595 \mathrm{~nm}$ and cell

18 proliferation equal to reduction of alamarBlue ${ }^{\mathrm{TM}}$ reagent was calculated according to the

19 supplier's manual. The plating density for HUVEC and length of incubation time with

20 alamarBlue ${ }^{\mathrm{TM}}$ was determined in preliminary experiments, as suggested by the supplier.

\subsection{Statistical analysis}

The data are expressed as mean \pm S.E.M. of values obtained in three to seven

24 experiments (pigs), each performed in duplicate. Levels of VEGF were standardized on

25 protein concentration per well (pg/ $\mu$ g protein). Statistical analyses were conducted using one- 
1 way ANOVA for repeated measurements followed by Dunnets's or Bonferroni's multiple 2 comparison post hoc tests (GraphPad PRISM v. 4.0, GraphPad Software, Inc., San Diego,

3 CA). Differences were considered to be statistically significant at $P<0.05$.

4

\section{3. Results}

63.1 Immunofluorescent localization of VEGF in stromal cell culture

7 Immunostaining for VEGF was detectable in stromal cells, with characteristic 8 morphology, after $48 \mathrm{~h}$ of culture and was localized in the cytosol (Fig. 1A, B). Negative 9 controls were consistently free from staining (Fig. 1C).

dose- and time-dependent manner (Fig. 2). Basal secretion of VEGF (pg/ $\mu$ g protein) increased

14 from $2.5 \pm 0.4(12 \mathrm{~h})$ to $5.3 \pm 0.6(48 \mathrm{~h})$. IGF-I-stimulated secretion of VEGF was detected 15 during all studied time-periods $(12-48 \mathrm{~h})$. Although, after $12 \mathrm{~h}$ only the highest dose of IGF-I was effective $(100 \mathrm{ng} / \mathrm{ml} ; P<0.05)$, longer incubation resulted in a significant enhance of

17 VEGF secretion from stromal cells at all tested doses $(P<0.01)$. The most effective action of IGF-I was found after $48 \mathrm{~h}$ of incubation, when VEGF concentration in medium increased 1.8 -fold for doses 10 and $100 \mathrm{ng} / \mathrm{ml}(8.1 \pm 0.5$ and $8.2 \pm 0.6$ vs $4.6 \pm 0.4$, respectively; $P<$ 20 0.01). Effect of RLX on VEGF release was observed only after 24 and $48 \mathrm{~h}$ of incubation, 21 when two or all used doses significantly stimulated secretion of VEGF, respectively $(P<$ 22 0.01). Long-term exposure (48 h) of stromal cells to $100 \mathrm{ng} / \mathrm{ml} \mathrm{RLX}$ led to maximal 1.8 -fold increase of VEGF release $(11.0 \pm 1.7$ vs $6.0 \pm 1.1 ; P<0.01)$. 


\subsection{Effect of OT and PGE ${ }_{2}$ on VEGF secretion}

Release of VEGF from cultured stromal cells was affected by both dose of OT or

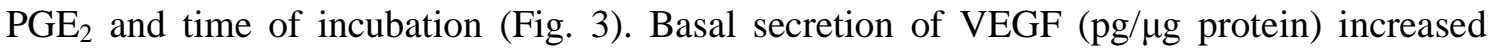
from $1.9 \pm 0.4(6 \mathrm{~h})$ to $4.6 \pm 0.2(48 \mathrm{~h})$. Although, OT seemed to inhibit VEGF secretion starting from $6 \mathrm{~h}$ of incubation, significant effect was detected only after 24 and $48 \mathrm{~h}$, when $100 \mathrm{nM}$ OT was used $(3.4 \pm 0.6$ vs $4.0 \pm 0.7, P<0.05$ and $3.4 \pm 0.7$ vs $4.9 \pm 0.2, P<0.01$; respectively). An augmentation of VEGF secretion by $\mathrm{PGE}_{2}$ in stromal cells was detected as early as $6 \mathrm{~h}$, but exclusively for $1 \mu \mathrm{M} \mathrm{PGE}_{2}$ (1.4-fold, $P<0.05$ ). However, the most effective action of $\mathrm{PGE}_{2}$ was observed after $48 \mathrm{~h}$ of incubation, when amounts of VEGF released into medium were induced approximately 1.3 -fold for doses 0.1 and $1 \mu \mathrm{M}(5.4 \pm 0.5$ and $5.8 \pm 0.3$ vs $4.4 \pm 0.3, P<0.05, P<0.01$; respectively).

\subsection{Effect of IGF-I and RLX on VEGF gene expression}

The dose-dependent effect of IGF-I and RLX (for both 0-100 ng/ml) on VEGF, VEGF164 and VEGF120 mRNA expression in stromal cells after $24 \mathrm{~h}$ of treatment is shown on Figure 4. The expression of VEGF, VEGF164 and VEGF120 mRNA was affected only by 50 and $100 \mathrm{ng} / \mathrm{ml}$ IGF-I $(P<0.05)$. The maximal, almost 2-fold increase of VEGF, VEGF164 and VEGF120 mRNA expression was observed when the highest dose of IGF-I was used $(100 \mathrm{ng} / \mathrm{ml} ; P<0.01, P<0.05$ and $P<0.05$, respectively). Although VEGF and VEGF164 expression was induced by 50 and $100 \mathrm{ng} / \mathrm{ml} \operatorname{RLX}(P<0.05$ and $P<0.01$, respectively), VEGF120 expression was significantly increased when the highest dose was used $(P<0.05)$. The maximal stimulation of VEGF, VEGF164 and VEGF120 mRNA expression was found in cells stimulated with $100 \mathrm{ng} / \mathrm{ml}$ RLX (1.6-, 1.8 - and 1.5-fold; $P<0.01, P<0.01, P<0.05$, respectively). 


\subsection{Effect of $O T$ and $P G E_{2}$ on VEGF gene expression}

Figure 5 shows the dose-dependent effect of OT $(0-100 \mathrm{nM})$ and $\mathrm{PGE}_{2}(0-1 \mu \mathrm{M})$ on VEGF, VEGF164 and VEGF120 mRNA expression in endometrial stromal cells after $24 \mathrm{~h}$ of incubation. In OT-treated cells tendency to decreased expression of VEGF, VEGF164 and VEGF120 mRNA was observed, however significant inhibition was only detected for dose $100 \mathrm{nM}(P<0.05)$. Although, stimulation of VEGF, VEGF164 mRNA expression by $\mathrm{PGE}_{2}$ was dose-dependent, VEGF120 levels were maintained constant. The maximal induction (1.8fold) was obtained with $1 \mu \mathrm{M} \mathrm{PGE}_{2}$ for VEGF and 0.1 and $1 \mu \mathrm{M} \mathrm{PGE}_{2}$ for VEGF164 $(P<$ $0.05)$.

\subsection{Effect of IGF-I, RLX, OT and PGE $E_{2}$ on VEGFRs gene expression}

Table 2 shows the effect of IGF-I (0-100 ng/ml), RLX (0-100 ng/ml), OT (0-100 nM) and PGE $_{2}(0-1 \mu \mathrm{M})$ on VEGFR-1 and VEGFR-2 expression in endometrial stromal cells after $24 \mathrm{~h}$ of incubation. Both receptors mRNA expression in cells incubated with various concentrations of IGF-I, RLX, OT or $\mathrm{PGE}_{2}$ was not affected by the treatment.

\subsection{Endothelial cell proliferation assay}

The ability of media conditioned by porcine endometrial stromal cells after IGF-I or RLX treatment to affect HUVEC proliferation is shown on Figure 6. Both IGF-I and RLX conditioned media increased HUVEC proliferation $(P<0.001$ and $P<0.01$; respectively). The effect was comparable to the level of proliferation observed for the positive control (45.6 \pm 8.3 and $40.4 \pm 6.3$ vs $45.7 \pm 7.2$, respectively). sVEGFR-1 effectively neutralized the effect of IGF-I and RLX conditioned media on endothelial cell proliferation $(45.6 \pm 8.3$ vs $38.0 \pm$ 5.7; $P<0.05$ and $40.4 \pm 6.3$ vs $31.4 \pm 5.2 ; P<0.01$, respectively), whereas sVEGFR-2 had no significant effect on HUVEC proliferation stimulated by IGF-I and RLX conditioned media. 
1 Both soluble receptors had no affect on cell proliferation in controls, however sVEGFR-2

2 slightly increased HUVEC proliferation $(31.2 \pm 4.7$ vs $36.2 \pm 6.4 ; P>0.05)$.

3

4 4. Discussion

Several studies, using different animal models, have shown that periimplantation

6 period is critical for embryo implantation, pregnancy success as well as the future growth and

7 developmental potential of embryos. Since VEGF regulates periimplantation vascular

8 permeability in rodents (Rabbani and Rogers, 2001) and female mice treated with VEGF

9 antiserum on day 4 after mating (the normal day of implantation) fail to deliver any pups

10 (Rockwell et al., 2002) it is tempting to believe that VEGF is one of the factors of uterine

11 periimplantation environment being crucial for pregnancy success. Recent results have

12 indicated upregulation of VEGF164 protein in endometrium in the periimplantation period in

13 pigs that agrees with patterns of estradiol secretion by the conceptus (Kaczmarek et al, 2008).

14 Thus, we have investigated whether factors creating a unique microenvironment for

15 successful embryo implantation in pigs may affect VEGF-receptor system expression in the porcine endometrium.

17 Our study demonstrated, for the first time, the effect of IGF-I, RLX, OT and PGE 2 on

18 VEGF secretion and VEGF-receptor system mRNA expression in porcine endometrial

19 stromal cells from tissues collected during early gestation (days 10-12). Stromal cell cultures

20 were selected for in vitro experiments, since this cell population is present in the uterus in a

21 much higher number than luminal epithelial cells (Blackwell et al., 2003) and thus they are

22 expected to contribute to the synthesis of the major portion of biological molecules produced

23 by the endometrium. For example, Northern blot analysis revealed that porcine stromal cells

24 are the main source of IGF-I (Rodriguez-Sallaberry et al., 2001) and in vitro experiments

25 showed that stroma population collected on days 11-13 of pregnancy may produce more 
$1 \quad \mathrm{PGE}_{2}$ than $\mathrm{PGF}_{2 \alpha}$ (Zhang and Davis, 1991). The close proximity of stromal cells to the uterine

2 vascular bed also predestinates them to be the main source of factors regulating

3 vascularization and vessel permeability, such as VEGF. Recently, we have demonstrated that

4 uterine stroma may be an important source of VEGF during early pregnancy in pigs

5 (Kaczmarek et al, 2008). Furthermore, results of the present immunoflourescent staining

6 showed that after 48 h-long culture stromal cells were not deprived of VEGF expression.

7 During the periimplantation period, the porcine uterine endometrium and conceptuses

8 exhibit dramatic biochemical, structural and morphological changes (Geisert et al, 1982).

9 Prior to complete attachment to the endometrial epithelium, blastocysts are dependent upon

10 hormones and nutrients secreted by the uterine endometrium. The presence of the IGF system

11 in porcine endometrium as well as blastocyst suggests important paracrine/autocrine modes of

12 IGF-I action in the uterine environment. In addition to the positive action on uterine growth in

13 early pregnancy, uterine IGF-I is thought to be a critical component for the implantation

14 process (for a review see Simmen et al., 1995). The endometrial IGF-I concentration between

15 days 8-14 of pregnancy is maintained in constant levels $(21.1 \pm 1.9 \mathrm{ng} / \mathrm{g}$ tissue $)$, but its content in the uterine lumen increases and peaks at day 12 of pregnancy (approximately 2.5

$17 \mu \mathrm{g}$ of total recoverable IGF-I; Letcher at al., 1989). IGF-I has been proposed to increase 18 estrogen synthesis through stimulation of porcine conceptus aromatase gene expression 19 (Green et al., 1995). Although IGF-I was shown to influence VEGF expression in several cell

20 types under physiological conditions, endometrial expression of this factor was studied only

21 in human adenocarcinoma cells (Bermont et al., 2000). Therefore, the present results are the

22 first available data showing IGF-I as the potent stimulator of VEGF mRNA expression as

23 well as VEGF secretion in the normal endometrium, during early pregnancy in the

24 mammalian female. It seems that IGF-I, together with estrogens of embryonic origin, may be 
1 the main factor involved in regulation of VEGF, but not VEGFR, synthesis in endometrial

2 stroma during periimplantation period in pigs.

3 It is well established that the CL is the main source of circulating RLX throughout

4 pregnancy in several species, including pigs (for a review see Sherwood, 2004). Although

5 serum RLX levels rise gradually from about $0.15 \mathrm{ng} / \mathrm{ml}$ on day 6 to about $10 \mathrm{ng} / \mathrm{ml}$ on day

6110 of pregnancy (Anderson et al., 1983; Eldridge-White et al., 1989), it seems unlikely that

7 this hormone exerts important effects during early gestation in pigs. However, it is tempting

8 to believe that small amounts of RLX produced locally by the endometrium may support

9 implantation through autocrine/paracrine mechanisms. Interestingly, RLX immunoactivity

10 and mRNA was localized between days 10-20 of pregnancy in pigs (Knox et al., 1994). On

11 the other hand, in humans, having a placentation type different to the porcine, circulating

12 RLX is highest during the first trimester (Stewart et al., 1990). Nevertheless, clinical

13 observation makes it seem unlikely that circulating RLX is an important factor during

14 implantation in humans. Further experiments demonstrating local synthesis of RLX in human

15 endometrial cells and its positive effect on VEGF expression (Unemori et al., 1999; Palejwala

16 et al., 2002) led to the hypothesis that this hormone supports uterine vascular events needed

17 for implantation and pregnancy maintenance in humans. Similarly, we showed that porcine

18 stromal cells secrete increased amounts of VEGF in response to RLX treatment. The present

19 results suggest that, also in pigs, endometrial RLX may be involved in regulation of

20 vasculature function within the endometrium during implantation through the control of

21 VEGF expression. However, definitive studies are needed to verify that hypothesis.

The uterotropic actions of exogenous RLX are pronounced in ovariectomized gilts

23 receiving estrogen as well as progesterone (Hall et al., 1992). The important synergism is

24 thought to exist between conceptus-derived estrogen and uterine-derived RLX that stimulate

25 uterine growth during the early stages of conceptus attachment and placentation (Knox et al., 
1 1994). Since RLX was more effective in stimulation of VEGF164 than VEGF120 mRNA

2 expression, it seems likely that previously established specific pattern of VEGF164

3 expression during early pregnancy in the pig (Kaczmarek et al., 2008) is a result of the

4 synergistic action of estrogen of embryonic origin and endometrial RLX.

In addition to direct action through specific receptor and initiation of a signal transduction cascade, RLX may exert its biological effects indirectly by influencing production of growth factors and/or their availability. The involvement of the uterine IGF system in the local action of RLX was demonstrated by coincidence of increased uterine weight and protein synthesis with a significant enhancement of uterine luminal content of IGFs and IGF-binding proteins (IGFBP), but not IGF-I-receptor expression in the uterus (Ohleth et al., 1997). Thus, induction of mRNA expression and secretion of VEGF in cultured porcine endometrial stromal cells by RLX may be additionally mediated via stimulation of IGF-I expression. Collectively, the evidence for the local production of RLX by the pig endometrium around the time of implantation (Knox et al., 1994) together with the RLXinduced increase in IGF-I secretion by the endometrium (Ohleth et al., 1997) and presently observed stimulation of VEGF expression in stromal cells by both, IGF-I and RLX support an important role of these factors in preparation of a suitable environment for pregnancy success in the pig.

Moreover, PGs are thought to be pivotal for establishment of pregnancy in the pig, since inhibition of its synthesis results in pregnancy failure (Kraeling et al., 1985). On days 11-12 of gestation, embryo-derived estrogens provide a signal for maternal recognition of pregnancy and increase $\mathrm{PGE}_{2} / \mathrm{PGF}_{2 \alpha}$ ratio due to augmented production of luteoprotective $\mathrm{PGE}_{2}$ (Davis and Blair, 1993; Christenson et al., 1994). In addition, during implantation prostaglandins are thought to participate in important vascular events: modulation of blood flow and increase of vascular permeability (Ford et al., 1982; Keys et al., 1986; Keys and 
1 King, 1988). $\mathrm{PGE}_{2}$ has been shown to upregulate VEGF in a number of tissues; however there

2 is only one report demonstrating transcriptional regulation of $\underline{V E G F}$ gene expression in the

3 uterus (Lopes et al., 2006). Interestingly, we found $\mathrm{PGE}_{2}$ to significantly increase VEGF164

4 mRNA levels in porcine endometrial stromal cells, whereas VEGF120 and VEGFR mRNA

5 was not affected by the treatment. Halder et al. (2000) showed that VEGF164 is one of the

6 primary mediators of VEGF signaling in the uterine vascular changes during implantation in

7 mice. Thus, it appears that $\mathrm{PGE}_{2}$ may be involved in induction of vascular permeability

8 during implantation time in the pig, by improving VEGF164 secretion from endometrial

9 stroma.

10 The presence of a low concentration of OTR in the endometrium during early

11 pregnancy (Okano et al., 1996) at first suggested that OT, known inducer of uterine PGF $_{2 \alpha}$

12 secretion, is involved in the process of maternal recognition of pregnancy in pigs (Carnahan et

13 al., 1996; Edgerton et al., 1996). Further demonstration that endometrial sensitivity to OT is

14 not regulated primarily through changes in OTR population density (Ludwig et al., 1998) and

15 blocking of OTR did not prevent luteolysis in pigs (Kotwica et al., 1999) deflated mandatory

16 role OT in establishment of pregnancy in pigs. This study provides the first demonstration of

17 OT-mediated inhibition of VEGF secretion as well as mRNA expression in endometrial

18 stromal cells from early pregnancy. In our experiments, only the highest dose of OT was

19 effective in inhibition of VEGF secretion and mRNA expression. This concentration of OT

$20(100 \mathrm{nM})$ is substantially higher than was reported in the peripheral circulation during

21 luteolysis in pigs (Kotwica et al., 1990). However, as it was reported for RLX, porcine

22 endometrium could be a source of OT during pregnancy (Boulton et al., 1996). Although it

23 was suggested that OT is a rather redundant component of the uterine environment during

24 maternal recognition of pregnancy, our present results suggest that high doses of OT, apart 
1 from stimulation of luteolytic $\mathrm{PGF}_{2 \alpha}$ secretion from uterus, are able to affect the process of

2 uterine vascularization and vascular permeability during early pregnancy in pigs.

3 Although all tested factors affected secretion and mRNA expression of VEGF,

4 VEGFR-1 and VEGFR-2 mRNA levels were maintained at a very low and constant level,

5 without significant stimulatory or inhibitory effects. The result is not surprising since the

6 dominant localization VEGFRs was found not in stromal, but in uterine capillary endothelial

7 cells in pigs (Charnock-Jones et al., 2001; Kaczmarek et al., 2008). The examined factors may

8 have also some effects on receptors in intact tissue if they are produced in stromal cells.

9 VEGF may act therefore directly on endothelial cells and also as a chemokine in attracting

endothelial cell migration during the outgrowth of new vessels in the endometrium.

11 In the present study, proliferation of HUVEC in vitro was induced directly by media

12 conditioned by stromal cells collected after IGF-I and RLX treatment. These effects were

13 blocked by sVEGFR-1, suggesting that IGF-I- and RLX-stimulated VEGF is able to induce

14 endothelial cells proliferation. More significant inhibition of HUVEC proliferation by media

15 conditioned by stromal cells collected after RLX treatment, may have an explanation in our

16 gene expression studies, where levels of highly mitogenic VEGF164 mRNA were induced by

17 RLX in a grater manner comparing to IGF-I. In contrast, sVEGFR-2 (no naturally occurring

18 splice variant) was not able to significantly inhibit HUVEC proliferation; however such a

19 tendency was observed. Like other growth factor transmembrane tyrosine kinase receptors,

20 VEGF receptors presumably undergo ligand-induced dimerization to activate transduction

21 pathways. Thus, dimers between sVEGFR and full-length VEGF receptor block signal

22 pathways dependent on intracellular tyrosine kinase dimerization. Both soluble receptors used

23 in the experiment has the same $\mathrm{ED}_{50}$ for VEGF-dependent proliferation of HUVEC provided

24 by the supplier (10-30 $\mathrm{ng} / \mathrm{ml})$, therefore the reason of such observation in a present study may

25 rather not lay in a dose of the sVEGFR used in a culture. However, previous results showed 
1 that VEGFR-1 and its soluble form bind VEGF with higher affinity (approximately $\mathrm{K}_{\mathrm{d}}$ 10-20

2 pM; de Vries et al., 1992; Kendall and Thomas, 1993) than VEGFR-1 (approximately $\mathrm{K}_{\mathrm{d}}$ 75-

$3125 \mathrm{pM}$; Terman et al., 1992). On the other hand, sVEGFR-2 seemed to increase the cell

4 proliferation in vitro itself, thus it is possible that its action on VEGF-stimulated proliferation

5 of HUVEC was masked by this effect in our experiment.

6 In summary, the present study is the first to demonstrate that VEGF-receptor system

7 expression in porcine endometrial stromal cells is controlled by factors creating a unique

8 microenvironment for successful embryo implantation in pigs. IGF-I and RLX are the most

9 potent inducers of VEGF secretion and mRNA expression, acting together with estrogens of

10 embryonic origin. Luteoprotective $\mathrm{PGE}_{2}$ was effective in stimulation of VEGF secretion as

11 well as VEGF164 mRNA expression suggesting its participation in vascular events during

12 implantation. In contrast, high doses of OT seem to inhibit VEGF-mediated actions in

13 endometrial stroma during early pregnancy in pigs. These results suggest that during the

14 periimplantation period essential crosstalk exists between examined factors that ensures

15 uterine and embryo development, implantation and pregnancy success by affecting uterine vasculature function. 


\section{Acknowledgements}

2 This research was supported by the State Committee for Scientific Research in Poland grant

3 No PBZ-KBN-084/P06/2002. We thank Mrs. K. Gromadzka-Hliwa, Mr. J. Klos for their

4 excellent technical assistance in the laboratory and Mr. M. Blitek for help in care and

5 handling of animals. We greatly acknowledge the expert technical assistance of Mrs. Gabi

6 Schwentker in radioimmunoassay. The research collaboration in this study was supported by

7 Roman Herzog Research Fellowship and Return Fellowship from Hertie and Alexander von

8 Humboldt Foundations (to M.M.K.). M.M. Kaczmarek was awarded the Domestic Grant for

9 Young Scientist from the Foundation for Polish Science. This work was partly presented on

10 the International Conference on Pig Reproduction, the Netherlands, 12-15 June 2005 and the

11 Annual Meeting of the ESDAR, Germany, 20-22 September 2007. 


\section{References}

2 Anderson, L.L., Adair, V., Stromer, M.H., McDonald, W.G., 1983. Relaxin production and 3 release after hysterectomy in the pig. Endocrinology 113, 677-686.

4 Anthony, F.W., Wheeler, T., Elcock, C.L., Pickett, M., Thomas, E.J., 1994. Short report:

5 identification of a specific pattern of vascular endothelial growth factor mRNA expression

6 in human placenta and cultured placental fibroblasts. Placenta 15, 55-561.

7 Berisha, B., Schams, D., Kosmann, M., Amselgruber, W., Einspanier, R., 2000. Expression 8 and tissue concentration of vascular endothelial growth factor, its receptors, and 9 localization in the bovine corpus luteum during estrous cycle and pregnancy. Biol. $10 \quad$ Reprod. 63, 1106-1114.

11 Bermont, L., Lamielle, F., Fauconnet, S., Esumi, H., Weisz, A., Adessi, G.L., 2000. 12 Regulation of vascular endothelial growth factor expression by insulin-like growth factor13 I in endometrial adenocarcinoma cells. Int. J. Cancer 85, 117-123.

14 Blackwell, D.M., Speth, R.C., Mirando, M.A., 2003. Morphometric analysis of the uterine 15 endometrium of swine on days 12 and 16 postestrus. Anat. Rec. 270, 59-66.

16 Blitek, A., Ziecik, A.J., 2004. Prostaglandins F and E secretion by porcine epithelial and 17 stromal endometrial cells on different days of the oestrous cycle. Reprod. Domest. Anim.

Boshier, D.P., 1970. The pontamine blue reaction in pregnant sheep uteri. J Reprod. Fertil. 22, $39,340-346$.

21 Boulton, M.I., McGrath, T.J., Goode, J.A., Broad, K.D., Gilbert, C.L., 1996. Changes in 22 content of mRNA encoding oxytocin in the pig uterus during the oestrous cycle, 23 pregnancy, at parturition and in lactational anoestrus. J. Reprod. Fertil. 108, 219-227. 
1 Bradford, M.M., 1976. A rapid and sensitive method for the quantitation of microgram

2 quantities of protein utilizing the principle of protein-dye binding. Anal. Biochem. 72, $3 \quad 248-254$.

4 Carnahan, K.G., Prince, B.C., Mirando, M.A., 1996. Exogenous oxytocin stimulates uterine 5 secretion of prostaglandin F2 alpha in cyclic and early pregnant swine. Biol. Reprod. 55, $6 \quad 838-843$.

7 Charnock-Jones, D.S., Clark, D.E., Licence, D., Day, K., Wooding, F.B., Smith, S.K., 2001 8 Distribution of vascular endothelial growth factor (VEGF) and its binding sites at the 9 maternal-fetal interface during gestation in pigs. Reproduction 122, 753-760.

10 Christenson, R.K., Farley, D.B., Anderson, L.H., Ford, S.P., 1994. Luteal maintenance during 11 early pregnancy in the pig: role for prostaglandin E2. Prostaglandins 47, 61-75.

12 Davis, D.L., Blair, R.M., 1993. Studies of uterine secretions and products of primary cultures 13 of endometrial cells in pigs. J. Reprod. Fertil. Suppl. 48, 143-155.

14 de Vries, C., Escobedo, J.A., Ueno, H., Houck, K., Ferrara, N., Williams, L.T., 1992. The 15 fms-like tyrosine kinase, a receptor for vascular endothelial growth factor. Science 255, $16989-991$.

17 Dey, S.K., Lim, H., Das, S.K., Reese, J., Paria, B.C., Daikoku, T., Wang, H., 2004. Molecular 18 cues of implantation. Endocrine Rev. 25, 341-373.

19 Dvorak, H.F., Brown, L.F., Detmar, M., Dvorak, A.M., 1995. Vascular permeability 20 factor/vascular endothelial growth factor, microvascular hyperpermeability, and 21 angiogenesis. Am. J. Pathol. 146, 1029-1039.

22 Edgerton, L.A., Kaminski, M.A., Silvia, W.J., 1996. Changes in uterine secretion of 23 prostaglandin F2 alpha in response to oxytocin during the estrous cycle, early pregnancy, 24 and estrogen-induced pseudopregnancy in swine. Biol. Reprod. 55, 657-662. 
1 Eldridge-White, R., Easter, R.A., Heaton, D.M., O’Day, M.B., Petersen, G.C., Shanks, R.D.,

2 Tarbell, M.K., Sherwood, O.D., 1989. Hormonal control of the cervix in pregnant gilts. I.

3 Changes in the physical properties of the cervix correlate temporally with elevated serum

4 levels of estrogen and relaxin. Endocrinology 125, 2996-3003.

5 Enders, A.C., Hendrickx, A.G., Schlafke, S., 1983. Implantation in the rhesus monkey: initial

6 penetration of endometrium. Am. J. Anat. 167, 275-298.

7 Ferrara N, Gerber HP, LeCouter J. 2003. The biology of VEGF and its receptors. Nat. Med. 9, $8 \quad 669-676$.

9 Ferrara, N., Houck, K.A., Jakeman, L.B., Winer, J., Leung, D.W., 1991. The vascular 10 endothelial growth factor family of polypeptides. J. Cell. Biochem. 47, 211-218.

11 Ford, S.P., Christenson, R.K., 1979. Blood flow to uteri of sows during the estrous cycle and 12 early pregnancy: local effect of the conceptus on the uterine blood supply. Biol. Reprod. $13 \quad 21,617-624$.

14 Ford, S.P., Reynolds, L.P., Magness, R.R., 1982. Blood flow to the uterine and ovarian 15 vascular beds of gilts during the estrous cycle and early pregnancy. Biol. Reprod. 27, 878$16 \quad 885$.

17 Geisert, R.D., Renegar, R.H., Thatcher, W.W., Roberts, R.M., Bazer, F.W., 1982. 18 Establishment of pregnancy in the pig: I. Interrelationships between preimplantation 19 development of the pig blastocyst and uterine endometrial secretions. Biol. Reprod. 27, $20 \quad 925-939$.

21 Green, M.L., Simmen, R.C., Simmen, F.A., 1995. Developmental regulation of steroidogenic 22 enzyme gene expression in the periimplantation porcine conceptus: a paracrine role for 23 insulin-like growth factor-I. Endocrinology 136, 3961-3970.

24 Halder, J.B., Zhao, X., Soker, S., Paria, B.C., Klagsbrun, M., Das, S.K., Dey, S.K., 2000. 25 Differential expression of VEGF isoforms and VEGF(164)-specific receptor neuropilin-1 
1 in the mouse uterus suggests a role for $\operatorname{VEGF}(164)$ in vascular permeability and 2 angiogenesis during implantation. Genesis 26, 213-224.

3 Hall, J.A., Cantley, T.C., Galvin, J.M., Day, B.N., Anthony, R.V., 1992. Influence of ovarian

4 steroids on relaxin-induced uterine growth in ovariectomized gilts. Endocrinology 130, $5 \quad 3159-3166$.

6 Hyder, S.M., Chiappetta, C., Murthy, L., Stancel, G.M., 1997. Selective inhibition of 7 estrogen-regulated gene expression in vivo by the pure antiestrogen ICI 182,780.Cancer $8 \quad$ Res. $57,2547-2549$.

9 Kaczmarek, M.M., Kowalczyk, A.E., Waclawik, A., Schams, D., Ziecik, A.J., 2007. 10 Expression of vascular endothelial growth factor and its receptors in the porcine corpus 11 luteum during the estrous cycle and early pregnancy. Mol. Reprod. Dev. 74, 730-739.

12 Kaczmarek, M.M., Waclawik, A., Blitek, A., Kowalczyk, A.E., Schams, D., Ziecik, A.J., 13 2008. Expression of the vascular endothelial growth factor-receptor system in the porcine 14 endometrium throughout the estrous cycle and early pregnancy. Mol. Reprod. Dev. 75, $15 \quad 362-372$.

Kendall, R.L., Thomas, K.A., 1993. Inhibition of vascular endothelial cell growth factor activity by an endogenously encoded soluble receptor. Proc. Natl. Acad. Sci. U.S.A. 90,

19 Keys, J.L., King, G.J., 1988. Morphological evidence for increased uterine vascular 20 permeability at the time of embryonic attachment in the pig. Biol. Reprod. 39, 473-487.

21 Keys, J.L., King, G.J., Kennedy, T.G., 1986. Increased uterine vascular permeability at the 22 time of embryonic attachment in the pig. Biol. Reprod. 34, 405-411.

23 Klotz, D.M., Hewitt, S.C., Ciana, P., Raviscioni, M., Lindzey, J.K., Foley, J., Maggi, A., 24 DiAugustine, R.P., Korach, K.S., 2002. Requirement of estrogen receptor-alpha in 
1 insulin-like growth factor-1 (IGF-1)-induced uterine responses and in vivo evidence for

2 IGF-1/estrogen receptor cross-talk. J. Biol. Chem. 277, 8531-8537.

3 Knox, R.V., Zhang, Z., Day, B.N., Anthony, R.V., 1994. Identification of relaxin gene

4 expression and protein localization in the uterine endometrium during early pregnancy in

$5 \quad$ the pig. Endocrinology 135, 2517-2525.

6 Kotwica, G., Dusza, L., Ciereszko, R., Okrasa, S., Schams, D., 1990. Oxitocin plasma levels 7 during spontaneous and cloprostenol-induced luteolysis in sows. Anim. Repro. Sci. 22, $8 \quad 109-119$.

9 Kotwica, G., Franczak, A., Okrasa, S., Kotwica, J., 1999. Effect of an oxytocin antagonist on 10 prostaglandin F2 alpha secretion and the course of luteolysis in sows. Acta Vet. Hung. 47, $11 \quad 249-262$.

12 Kowalczyk, A.E., Kaczmarek, M.M., Schams, D., Ziecik, A.J., 2008. Effect of prostaglandyn 13 E2 and tumor necrosis factor $\alpha$ on the VEGF-receptor system expression in cultured 14 porcie luteal cells. Mol. Reprod. Dev. (DOI: 10.1002/mrd.20897).

15 Kraeling, R.R., Rampacek, G.B., Fiorello, N.A., 1985. Inhibition of pregnancy with 16 indomethacin in mature gilts and prepuberal gilts induced to ovulate. Biol. Reprod. 32, $17 \quad 105-110$

Lei, J., Jiang, A., Pei, D., 1998. Identification and characterization of a new splicing variant of 19 vascular endothelial growth factor: VEGF183. Biochim. Biophys. Acta 1443:400-406.

20 Letcher, R., Simmen, R.C., Bazer, F.W., Simmen, F.A., 1989. Insulin-like growth factor-I 21 expression during early conceptus development in the pig. Biol. Reprod. 41, 1143-1151.

22 Lopes, F.L., Desmarais, J., Ledoux, S., Gevry, N.Y., Lefevre, P., Murphy, B.D., 2006.

23 Transcriptional regulation of uterine vascular endothelial growth factor during early 24 gestation in a carnivore model, Mustela vison. J. Biol. Chem. 281, 24602-24611. 
1 Ludwig, T.E., Sun, B.C., Carnahan, .KG., Uzumcu, M., Yelich, J.V., Geisert, R.D., Mirando,

2 M.A., 1998. Endometrial responsiveness to oxytocin during diestrus and early pregnancy

3 in pigs is not controlled solely by changes in oxytocin receptor population density. Biol.

$4 \quad$ Reprod. 58, 769-777.

5 Ohleth, K.M., Lenhart, J.A., Ryan, P.L., Radecki, S.V., Bagnell, C.A., 1997. Relaxin

6 increases insulin-like growth factors (IGFs) and IGF-binding proteins of the pig uterus in

$7 \quad$ vivo. Endocrinology 138, 3652-3658.

8 Okano, A., Okuda, K., Takahashi, M., Schams, D., 1996. Oxitocin receptors in the porcie

9 endometrium during the estrous cycle and early pregnancy. Anim. Reprod. Sci. 41, 61-70.

10 Palejwala, S., Tseng, L., Wojtczuk, A., Weiss, G., Goldsmith, L.T., 2002. Relaxin gene and

11 protein expression and its regulation of procollagenase and vascular endothelial growth

12 factor in human endometrial cells. Biol. Reprod. 66, 1743-1748.

13 Pillai, S.B., Rockwell, L.C., Sherwood, O.D., Koos, R.D., 1999. Relaxin stimulates uterine 14 edema via activation of estrogen receptors: blockade of its effects using ICI 182,780, a 15 specific estrogen receptor antagonist. Endocrinology 140, 2426-2429.

Psychoyos, A., 1973. Endocrine control of egg implantation. In: Greep, R.O., Astwood, E.G.,

17 Geiger, S.R. (ed.), Handbook of physiology. American Physiology Society, Washington, pp. 187-215.

Rabbani, M.L., Rogers, P.A., 2001. Role of vascular endothelial growth factor in endometrial vascular events before implantation in rats. Reproduction 122, 85-90.

Rockwell, L.C., Pillai, S., Olson, C.E., Koos, R.D., 2002. Inhibition of vascular endothelial growth factor/vascular permeability factor action blocks estrogen-induced uterine edema and implantation in rodents. Biol. Reprod. 67, 1804-1810.

Rodriguez-Sallaberry, C., Simmen, F.A., Simmen, R.C., 2001. Polyamine- and insulin-like growth factor-I-mediated proliferation of porcine uterine endometrial cells: a potential 
role for spermidine/spermine $\mathrm{N}(1)$-acetyltransferase during peri-implantation. Biol.

$2 \quad$ Reprod. 65, 587-594.

3 Sherwood, O.D., 2004 Relaxin's physiological roles and other diverse actions. Endocr. Rev. $4 \quad 25,205-234$.

5 Simmen, R.C.M., Greek, M.L., Simmen, F.A., 1995. IGF system in periimplantation uterus 6 and embrionie development. In: Dey, S.K. (ed.), Molecular and Cellular aspects of 7 Periimplantation Process. Springer-Verlag, New York, pp. 185-204.

8 Stewart, D.R., Celniker, A.C., Taylor Jr, C.A., Cragun, J.R., Overstreet, J.W., Lasley, B.L., 9 1990. Relaxin in the peri-implantation period. J. Clin. Endocrinol. Metab. 70, 1771-1773.

Gospodarowicz, D., Böhlen, P., 1992. Identification of the KDR tyrosine kinase as a

2

3
receptor for vascular endothelial cell growth factor. Biochem. Biophys. Res. Commun. $187,1579-1586$.

Tischer, E., Mitchell, R., Hartman, T., Silva, M., Gospodarowicz, D., Fiddes, J.C., Abraham, J.A., 1991. The human gene for vascular endothelial growth factor. Multiple protein forms are encoded through alternative exon splicing. J. Biol. Chem. 266, 11947-11954.

Unemori, E.N., Erikson, M.E., Rocco, S.E., Sutherland, K.M., Parsell, D.A., Mak, J., Grove, B.H., 1999. Relaxin stimulates expression of vascular endothelial growth factor in normal human endometrial cells in vitro and is associated with menometrorrhagia in women. Hum. Reprod. 14, 800-806.

Zhang, Z., Davis, D.L., 1991. Prostaglandin E and E2 alpha secretion by glandular and stromal cells of the pig endometrium in vitro: effects of estradiol-17 beta, progesterone, and day of pregnancy. Prostaglandins 42, 151-162. 
1 Ziecik, A.J., Blitek, A., Kaczmarek, M.M., Waclawik, A., Bogacki, M., 2006. Inhibition of

2 luteolysis and embryo-uterine interactions during the peri-implantation period in pigs.

3 Soc. Reprod. Fertil. Suppl. 62, 147-161.

4 


\section{$1 \quad$ Figure legends}

2 Fig. 1. Porcine endometrial stromal cells in culture. (A) Light microscopy of stromal cells

3 after $48 \mathrm{~h}$ after plating. (B) Immunofluorescent staining of porcine stromal cells for VEGF

4 protein expression. (C) Negative control. Magnification, x 400.

5

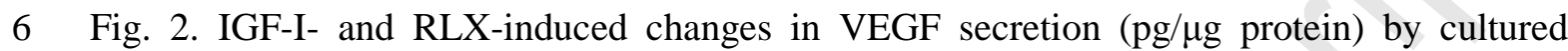

7 porcine endometrial stromal cells obtained on days 10-12 of pregnancy. Cells were incubated

8 with IGF-I or RLX (for both $0-100 \mathrm{ng} / \mathrm{ml})$ for $12 \mathrm{~h}(\mathrm{n}=3), 24 \mathrm{~h}(\mathrm{n}=7)$ and $48 \mathrm{~h}(\mathrm{n}=4)$. Data are

9 presented as means \pm S.E.M. $* P<0.05, * * P<0.01$ compared to controls.

11 Fig. 3. OT- and $\mathrm{PGE}_{2}$-induced changes in VEGF secretion ( $\mathrm{pg} / \mu \mathrm{g}$ protein) by cultured porcine endometrial stromal cells obtained on days 10-12 of pregnancy. Cells were incubated with OT $(0-100 \mathrm{nM})$ or $\mathrm{PGE}_{2}(0-1 \mu \mathrm{M})$ for $6 \mathrm{~h}(\mathrm{n}=4), 12 \mathrm{~h}(\mathrm{n}=3), 24 \mathrm{~h}(\mathrm{n}=7)$ and $48 \mathrm{~h}(\mathrm{n}=7)$. Data are presented as means \pm S.E.M. $* P<0.05, * * P<0.01$ compared to controls. expression in cultured porcine endometrial stromal cells obtained on days 10-12 of pregnancy. Cells were incubated with IGF-I or RLX (for both 0-100 ng/ml) for $24 \mathrm{~h}(\mathrm{n}=4)$. Data are presented as means \pm S.E.M. $* P<0.05$, $* * P<0.01$ compared to controls.

Fig. 5. Dose-dependent effect of OT and $\mathrm{PGE}_{2}$ on VEGF, VEGF164 and VEGF120 expression in cultured porcine endometrial stromal cells obtained on days 10-12 of pregnancy. Cells were incubated with OT $(0-100 \mathrm{nM})$ or $\mathrm{PGE}_{2}(0-1 \mu \mathrm{M})$ for $24 \mathrm{~h}(\mathrm{n}=3)$. Data are presented as means \pm S.E.M. $* P<0.05, * * P<0.01$ compared to controls. 
1 Fig. 6. Induction of endothelial cell proliferation by $35 \%$ of conditioned medium collected

2 after IGF-I (A; n=5) or RLX (B; n=4) treatment of porcine endometrial stromal cells. HUVEC

3 were cultured in control or conditioned medium in the absence or presence of sVEGFR-1 and

$4 \quad$ sVEGFR-2 $(100 \mathrm{ng} / \mathrm{ml})$. VEGF (10 $\mathrm{ng} / \mathrm{ml})$ was used as a positive control. Data are presented

5 as means \pm S.E.M.* $P<0.05, * * P<0.01, * * * P<0.001$.

6 
(Fig. 1)

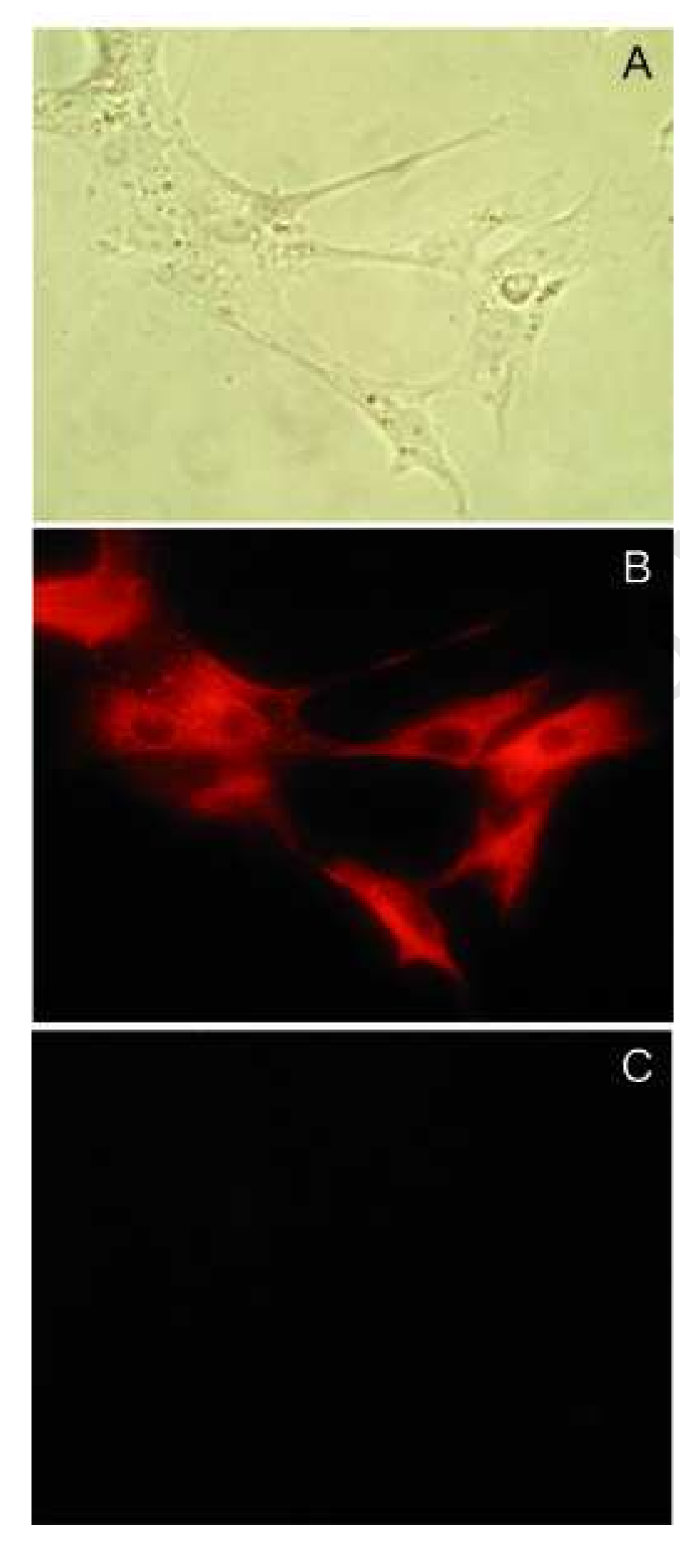

\section{Kaczmarek et al.}

.

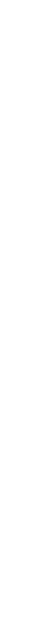

(
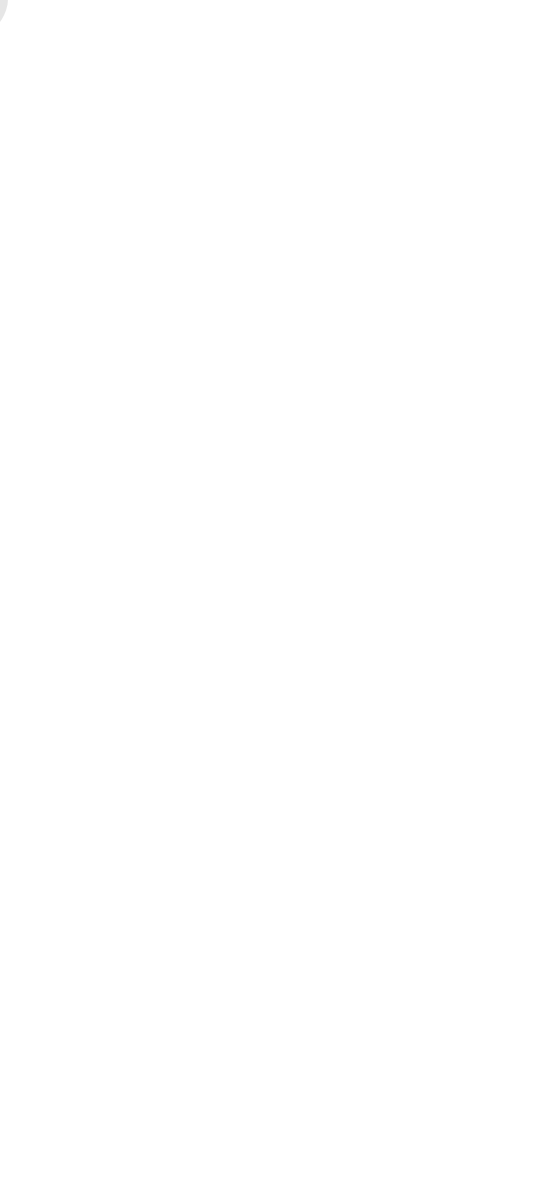
Kaczmarek et al.

(Fig. 2)

$12 \mathrm{~h}$
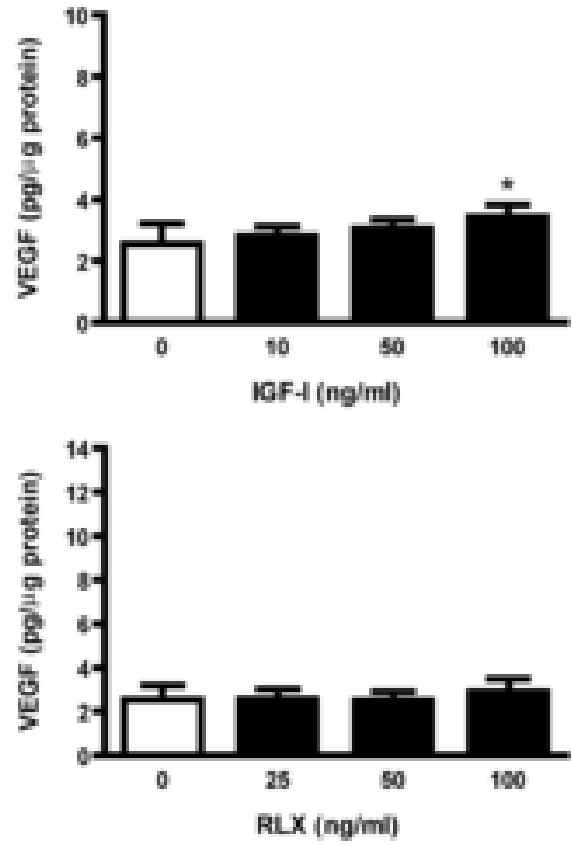

$24 \mathrm{~h}$
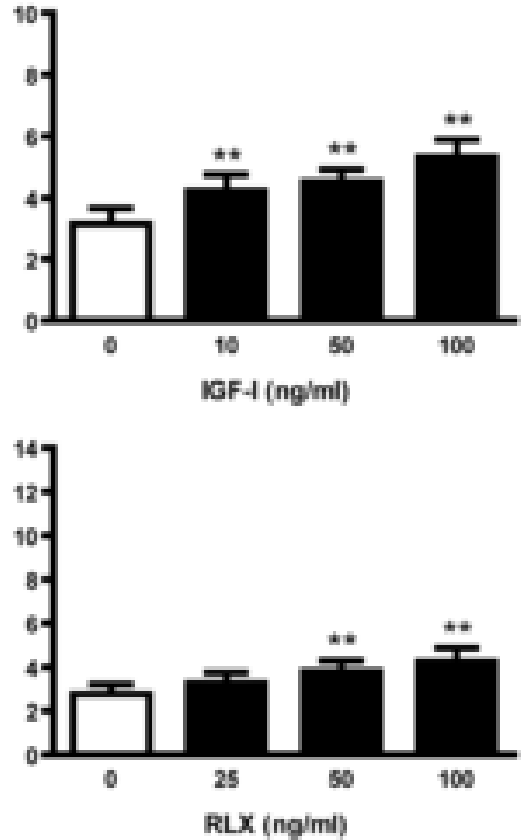

$48 \mathrm{~h}$
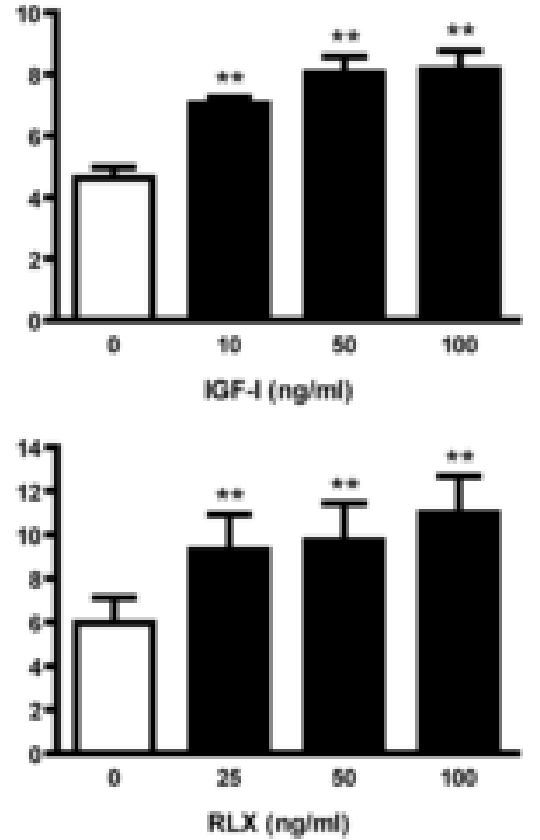
Kaczmarek et al.

(Fig. 3)
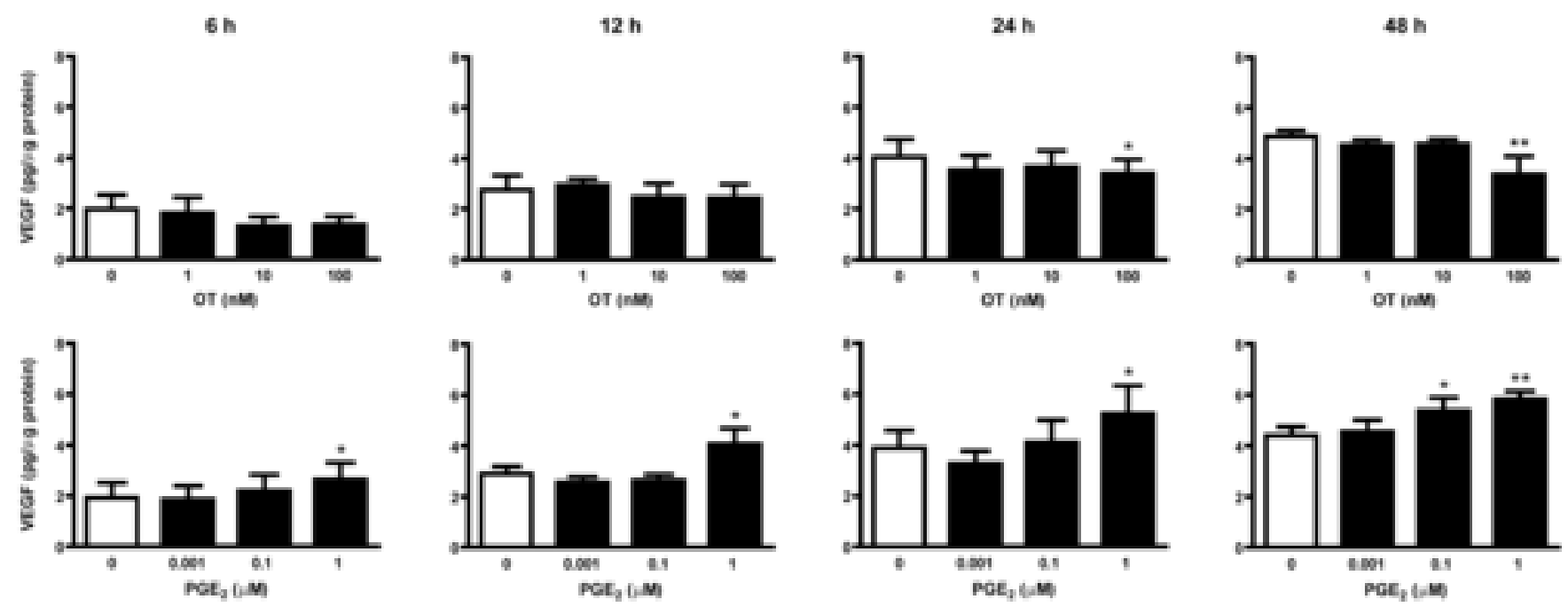

Page 33 of 38 
Kaczmarek et al.

(Fig. 4)
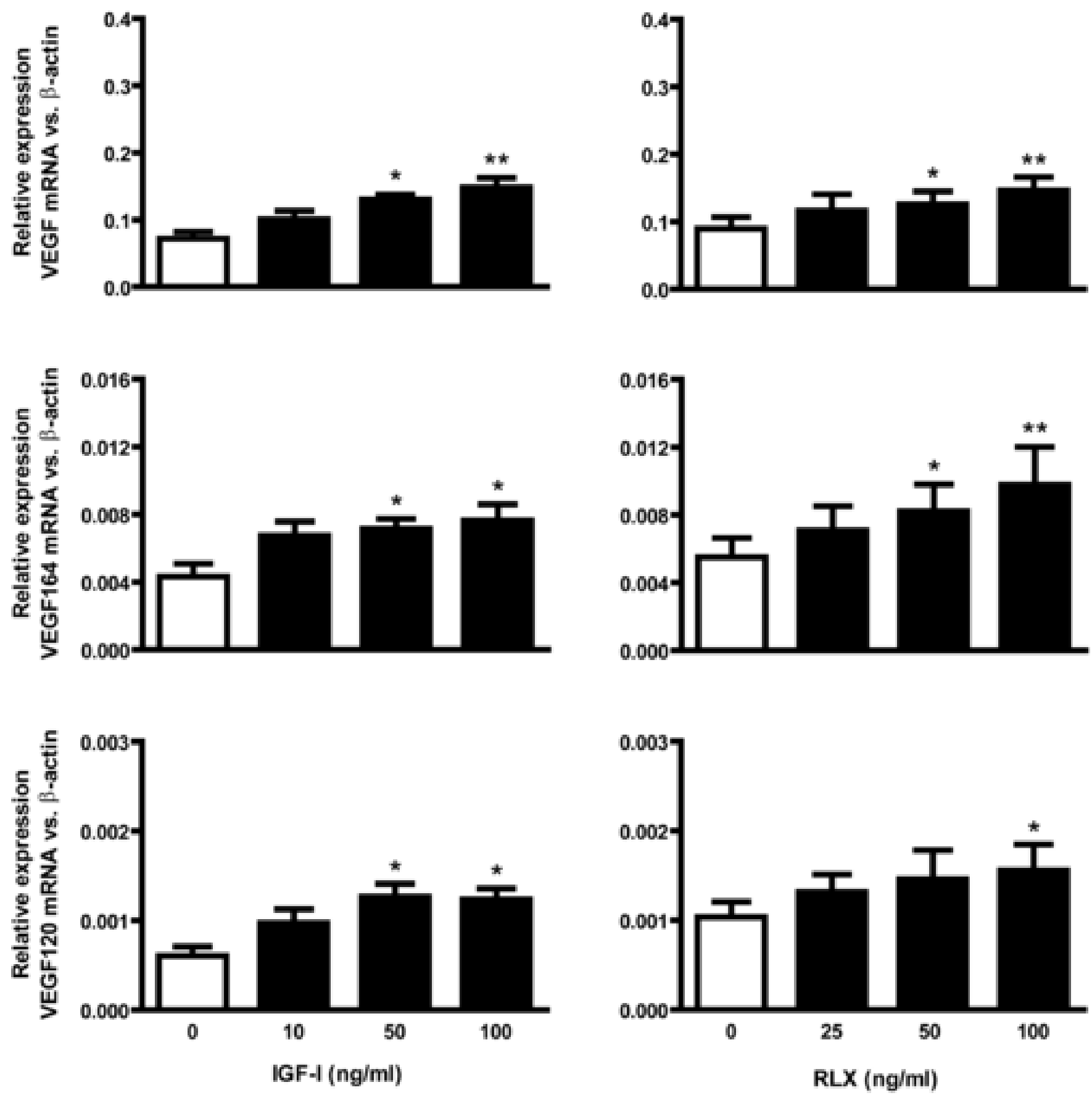
Kaczmarek et al.

(Fig. 5)
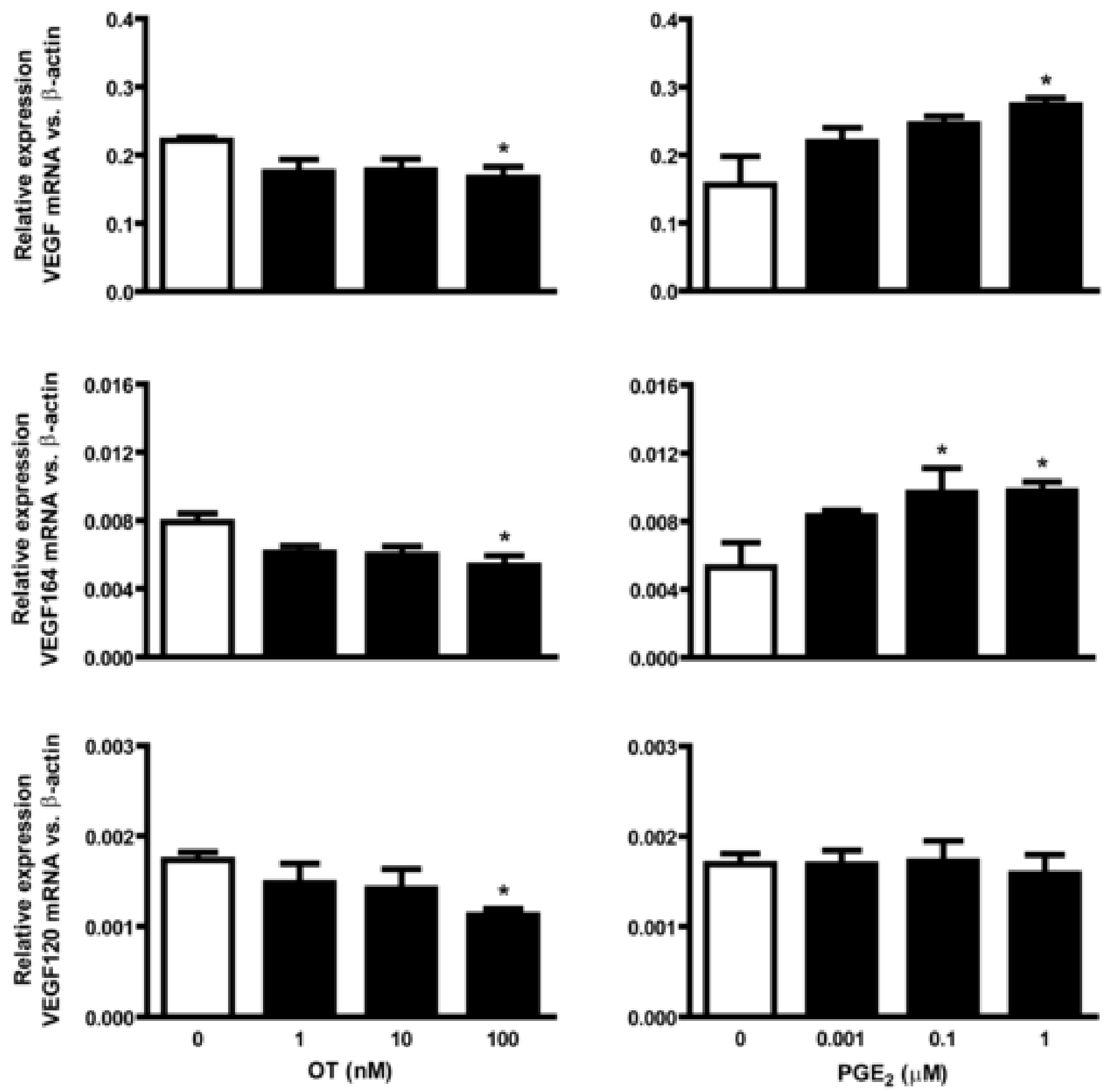

Page 35 of 38 
Kaczmarek et al.

(Fig. 6)

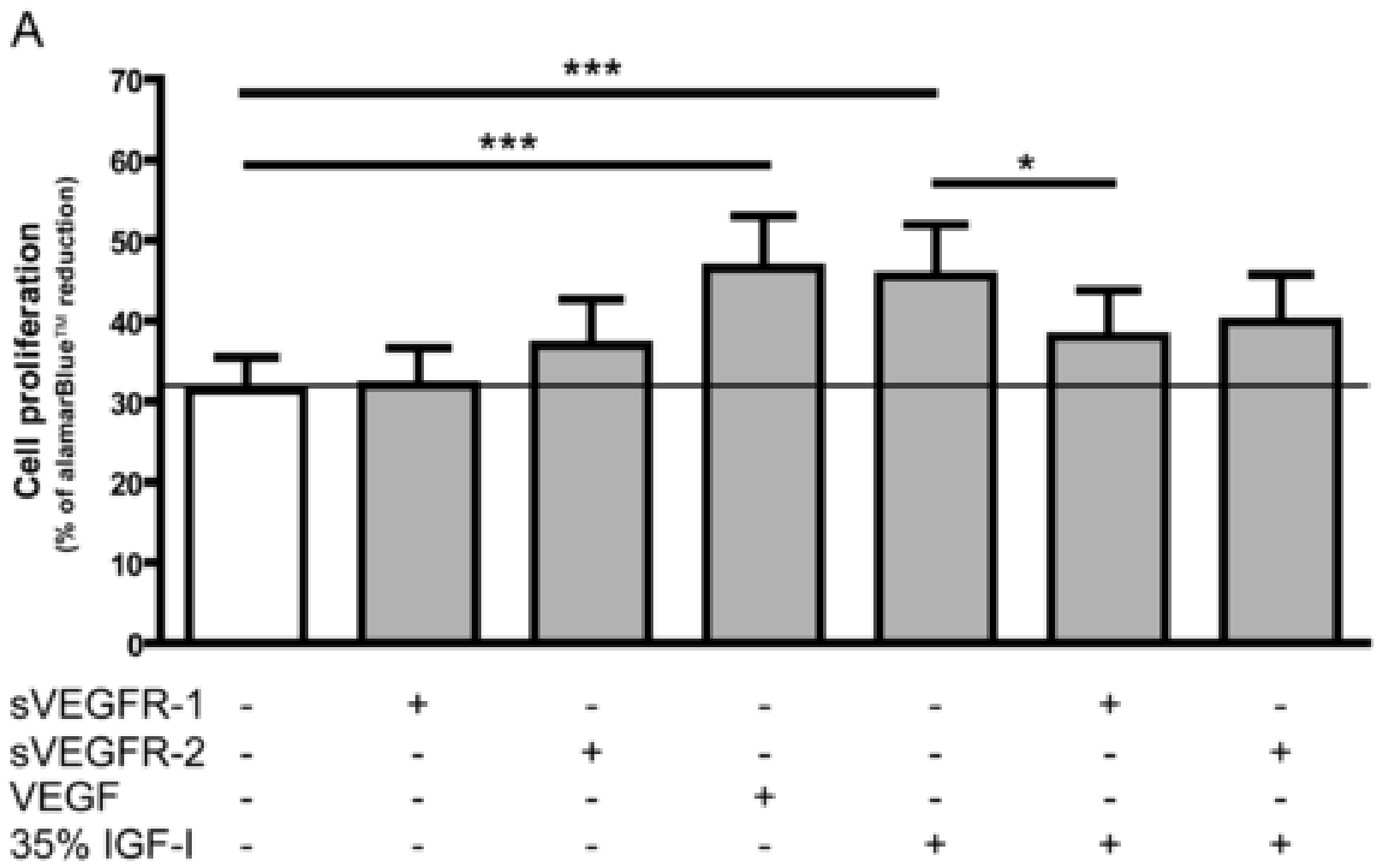

B

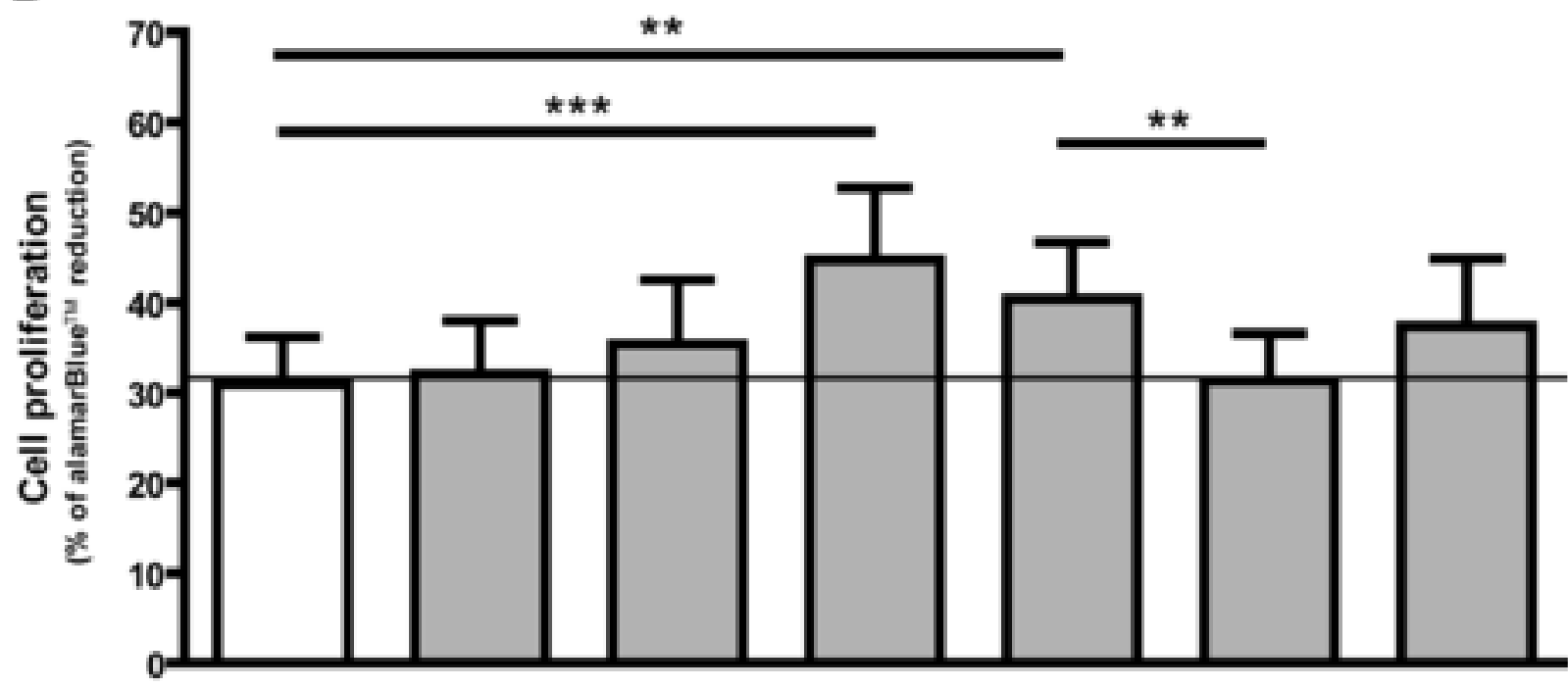

sVEGFR-1 SVEGFR-2 VEGF $35 \%$ RLX 


\section{Table 1}

Gene specific primers used for Real Time PCR

\begin{tabular}{|c|c|c|}
\hline Genes $^{\mathrm{a}}$ & Primers (5'-3') & Product size \\
\hline$\underline{V E G F}$ & $\begin{array}{l}\text { Forward: CCTGATGCGGTGCGGGGGCT } \\
\text { Reverse: TGGTGGTGGCGGCGGCTATG }\end{array}$ & $\begin{array}{l}\text { VEGF }_{188}: 510 \\
\text { VEGF }_{164}: 438 \\
\text { VEGF }_{120}: 306\end{array}$ \\
\hline$\underline{V E G F 164}$ & $\begin{array}{l}\text { Forward: GAGGCAAGAAAATCCCTGTG } \\
\text { Reverse: TCACATCTGCAAGTACGTTCG }\end{array}$ & 150 \\
\hline$\underline{V E G F 120}$ & $\begin{array}{l}\text { Forward: AAGGCCAGCACATAGGAGAG } \\
\text { Reverse: CCTCGGCTTGTCACATTTTT }\end{array}$ & 101 \\
\hline$\underline{V E G F R-1}$ & $\begin{array}{l}\text { Forward: CACCCCGGAAATCTATCAGATC } \\
\text { Reverse: GAGTACGTGAAGCCGCTGTTG }\end{array}$ & 180 \\
\hline$\underline{V E G F R-2}$ & $\begin{array}{l}\text { Forward: GATGCTCGCCTCCCTTTGA } \\
\text { Reverse: AGTTCCTTCTTTCAGTCGCCTACA }\end{array}$ & 180 \\
\hline$\beta$-actin & $\begin{array}{l}\text { Forward: ACATCAAGGAGAAGCTCTGCTACG } \\
\text { Reverse: GAGGGGCGATGATCTTGATCTTCA }\end{array}$ & 366 \\
\hline
\end{tabular}

${ }^{\mathrm{a}}$ See text for definitions. 
Table 2

Relative expression of VEGFR-1 and VEGFR-2 in porcine endometrial stromal cells after treatment

\begin{tabular}{|c|c|c|c|}
\hline \multirow{2}{*}{ Treatment } & & \multicolumn{2}{|c|}{ Relative expression $^{\mathrm{a}}$} \\
\hline & & VEGFR-1 vs. $\beta$-actin & VEGFR- 2 vs. $\beta$-actin \\
\hline \multirow{4}{*}{$\begin{array}{l}\text { IGF I (ng/ml) } \\
(n=4)\end{array}$} & 0 & $0.017 \pm 0.004$ & $0.002 \pm 0.0007$ \\
\hline & 10 & $0.017 \pm 0.005$ & $0.003 \pm 0.0010$ \\
\hline & 50 & $0.014 \pm 0.003$ & $0.003 \pm 0.0010$ \\
\hline & 100 & $0.015 \pm 0.003$ & $0.003 \pm 0.0007$ \\
\hline \multirow{4}{*}{$\begin{array}{l}\mathrm{RLX}(\mathrm{ng} / \mathrm{ml}) \\
(\mathrm{n}=4)\end{array}$} & 0 & $0.018 \pm 0.005$ & $0.002 \pm 0.0010$ \\
\hline & 25 & $0.020 \pm 0.005$ & $0.003 \pm 0.0013$ \\
\hline & 50 & $0.016 \pm 0.004$ & $0.002 \pm 0.0009$ \\
\hline & 100 & $0.019 \pm 0.004$ & $0.003 \pm 0.0009$ \\
\hline \multirow{4}{*}{$\begin{array}{l}\text { OT }(n M) \\
(n=3)\end{array}$} & 0 & $0.020 \pm 0.005$ & $0.007 \pm 0.0029$ \\
\hline & 1 & $0.021 \pm 0.007$ & $0.006 \pm 0.0015$ \\
\hline & 10 & $0.022 \pm 0.008$ & $0.006 \pm 0.0016$ \\
\hline & 100 & $0.024 \pm 0.007$ & $0.006 \pm 0.0026$ \\
\hline \multirow{4}{*}{$\begin{array}{l}\text { PGE2 }(\mu \mathrm{M}) \\
(\mathrm{n}=3)\end{array}$} & 0 & $0.018 \pm 0.004$ & $0.006 \pm 0.0017$ \\
\hline & 0.00 & $0.020 \pm 0.006$ & $0.007 \pm 0.0015$ \\
\hline & 0.1 & $0.021 \pm 0.006$ & $0.006 \pm 0.0021$ \\
\hline & 1 & $0.020 \pm 0.007$ & $0.005 \pm 0.0013$ \\
\hline
\end{tabular}

${ }^{\mathrm{a}}$ Data are presented as means \pm S.E.M. 